\title{
Lęk u osób niewidzących od urodzenia lub wczesnego dzieciństwa (ze szczególnym uwzględnieniem lęku wysokości)
}

Kwestie lęku, w tym lęku wysokości, u osób niewidomych są istotnym zagadnieniem nie tylko współczesnej edukacji i rehabilitacji osób niewidomych i niedowidzących. Jednakże pomimo wieloletniego zainteresowania daną tematyką problem obecności lęku wysokości u osób niewidomych od urodzenia lub wczesnego dzieciństwa, jego natury, a także możliwych objawów nie został jednoznacznie zdefiniowany do dnia dzisiejszego. Znaczna liczba osób z niepełnosprawnością wzrokową od urodzenia deklaruje brak obecności lęku wysokości, ale są również osoby, które zwracają uwagę na posiadanie tego typu lęku. Dlatego w artykule przedstawiono rozważania na temat lęku wysokości u osób niewidomych od urodzenia lub wczesnego dzieciństwa oraz wyniki badań własnych przeprowadzonych na grupie 10 osób (5 kobiet i 5 mężczyzn) na bazie metody indywidualnego przypadku i techniki wywiadu.

Słowa kluczowe: lęk, lęk wysokości, niewidzenie, osoba niewidoma, lęk wysokości u osób niewidomych

\section{Anxiety in people who are blind from birth or early childhood (with particular emphasis on fear of heights)}

Issues of anxiety, including fear of heights, for blind people are an important issue not only in modern education and rehabilitation of blind and visually impaired people. However, despite many years of interest in the topic, the problem of the presence of anxiety of height in people who have been blind since birth or early childhood, its nature, and possible symptoms has not been clearly defined to date. A significant number of people with visual disabilities from birth declare no height anxiety, but there are also people who pay attention to having this type of anxiety. Therefore, the article presents reflections on the fear of height in people blind from birth or early childhood and the results of own research conducted on a group of 10 people (5 women and 5 men) based on the individual case method and interview technique.

Keywords: bow, fear of heights, blindness, blind person, fear of heights for blind people 


\section{Wprowadzenie}

Stany lęku, lęk, a nawet lęk paniczny zapewne towarzyszyły ludziom od najdawniejszych czasów prehistorycznych. Posiadały (i posiadają do dziś) swoją specyfikę uzależnioną od epoki historycznej i/lub składu osobowości konkretnej istoty ludzkiej. Są warunkowane zarówno czynnikami o charakterze zewnątrzpochodnym, jak i wewnątrzpochodnym. Mogły/mogą objawiać się w różny sposób, posiadać niejednoznaczne nasilenie oraz dominację rodzaju lęku wpisaną w cechy epoki historycznej, jakość życia ludzi, ich mentalność, poziom rozwoju wiedzy o człowieku, nauki, techniki, poglądy filozoficzne interpretujące sens i celowość ludzkiego życia. Bez względu na rodzaj, stopień rozpowszechnienia czy specyfikę objawów, lęk był (i jest) nieobcy ludziom oraz wpisany w indywidualną i społeczną ich egzystencję, jak również w cywilizacyjną misję gatunku Homo Sapiens. Ludzie bowiem doświadczali i doświadczają różnego typu lęku, który - z racji współczesnej wiedzy naukowej - jest zjawiskiem coraz bardziej poznanym, tak w wymiarze przyczynowości, konsekwencji, ewentualnej terapii w okolicznościach, kiedy dezorganizuje lub zagraża życiu człowieka.

Skoro lęk bezpośrednio lub pośrednio koresponduje z naturą ludzką, to zasadniczo dotyczy wszystkich ludzi (w każdym razie populacyjnej większości), bez względu na ich stan somatyczny, psychofizyczny, status społeczny. Może jednak być determinowany, jak też specyfikowany, w kontekście rodzaju, poziomu nasilenia, formy, sposobu odczuwania, doświadczania, przejawiania konsekwencji. Dotyczy również środowiska osób z niepełnosprawnościami nie tylko w relacji z rodzajem niepełnosprawności, czy możliwością wyższego odsetkowego występowania problemu w porównaniu z populacją osób pełnosprawnych (np. u osób ze schorzeniami psychicznymi), ale także możliwej odmienności w odczuwaniu lęku lub różnych rodzajów lęku (np. u osób z niepełnosprawnością ruchową, niepełnosprawnościami sensorycznymi, autyzmem). Specyficzne zachowania ludzi z niektórymi rodzajami niepełnosprawności, nieuzyskujące na ogół akceptacji społecznej, określane jako zachowania autostymulacyjne (w tym między innymi sensoryzmy, blindyzmy) w wielu przypadkach posiadają lękogenną naturę (Delacato 1999).

Nie tyle specyficznych lęków, ile raczej specyficznych sposobów ich przeżywania, percepcji, identyfikacji doświadczają osoby niewidzące od urodzenia lub wczesnego dzieciństwa. Nie doświadczają bowiem np. lęku przed utratą wzroku (skotomafobii; scotomaphobii), lęku ciemności (skotofobii), które są obecne wśród osób widzących, ale doświadczają lub doświadczać mogą chociażby lęku otwartej przestrzeni (agorafobii), zamkniętych przestrzeni (klaustrofobii), podróżowania (dromofobii), czerwienienia się (ereutofobii) i prawdopodobnie wysokości (akro- 
fobii) (Pużyński 1993). Stąd, mając na względzie subtelność i szczególność przejawiania lęku u osób niewidzących od urodzenia lub wczesnego dzieciństwa bardziej wnikliwej analizie poddano zagadnienia lęku wysokości w danej grupie ludzkiej, lokując rozważania na ten temat w wymiarze wiedzy ogólnej, wiedzy skonkretyzowanej oraz szczegółowej, tj. co do odczuwania lęku wysokości przez osoby dorosłe niewidzące od urodzenia lub wczesnego dzieciństwa.

\section{Problematyką lęku w wymiarze definicyjnym, objawowym, klasyfikacyjnym}

Termin lęk (anxietas; ankiety - ang., ankieté - franc, ansiedad, angustia - hiszp., angst - niem.) (Pużyński 1993: 247) definiowany jest jako nieprzyjemna emocja, uczucie przykre, trwoga, niepokój stan z cechami obawy, roztrzęsienia i przerażenia. Jest to uczucie podobne do strachu, ale różniące się tym, że powstaje bez wyraźniej przyczyny. Jest to reakcja na subiektywne zagrożenie, czyli jest to poczucie zagrożenia przy braku obiektywnych czynników zagrażających (Karolczak--Biernacka 1998: 193-194). Lęk jest emocją, i jak każda emocja, jest reakcją na bodźce zewnętrzne (najczęściej społeczne) lub wewnętrzne (myśli, wyobrażenia, także bodźce pochodzące $z$ wnętrza organizmu). Lęk, jak inne emocje, jest zjawiskiem psychofizjologicznym, bazującym na procesach nerwowych, aktywizowanych głównie przez struktury pnia mózgu (Obuchowska 1993: 344). Należy odróżnić lęk „"normalny” od lęku "patologicznego"- nerwicowego. Różnica polega na większej intensywności, uporczywości i nieadekwatności do sytuacji lęku nerwicowego. „Normalny” lęk może mobilizować człowieka do pokonania trudnej sytuacji. Problemem jest jednak siła lęku, gdyż tylko do pewnego poziomu pobudzenia lęk działa mobilizująco, natomiast po jego przekroczeniu dezorganizuje działanie. Uczucie lęku jest doświadczane przez każdego człowieka, jest przeżyciem o cechach indywidualnych, jak również zmiennym w przebiegu ludzkiego życia (Obuchowska 1993: 344).

Lęk jako objaw stanu ludzkiego organizmu jest spotykany w wielu zaburzeniach psychicznych i somatycznych. Jako samodzielny zespół chorobowy pojawia się w skali od 5\% do 10\% populacji generalnej (Pużyński 1993: 247). Przyjmuje się również możliwość rodzinnych uwarunkować lęku - 18-20\% krewnych w pierwszej linii ujawnia zaburzenia lękowe (Pużyński 1993: 250).

W analizach zagadnienia lęku obecne są rozważania oraz dyskusje nad różnicowaniem lęku od strachu, fobii oraz stresu. Przyjmuje się, że strach (ang. fear) jest elementarną przykrą emocją, reakcją na zagrożenie obiektywne, bezpośrednie, fizyczne. Natomiast lęk, oprócz reakcji na zagrożenie obiektywne, wyraża się 
$\mathrm{w}$ reakcjach na zagrożenie psychiczne. Strach umożliwia zareagowanie na sytuację/sytuacje strach wywołujące, w lęku reakcje na zagrożenie są zablokowane. Lęk jest więc nierozstrzygniętych strachem. Stąd w różnicowaniu strachu i lęku bierze się pod uwagę kryterium rodzaju przyczyny powodującej poczucie zagrożenia (obiektywne-subiektywne) oraz możliwości zareagowania na zagrożenie. W rzeczywistości zróżnicowanie lęku od strachu jest bardzo trudne, a w wielu przypadkach niemożliwe (Karolczak-Biernacka 1998: 194). Przy różnicowaniu oraz definiowaniu lęku bierze się pod uwagę kwestie tzw. lęku utajnionego (obecności lęku bez jego świadomości) i jawnego (cechuje się tym, że osoba ma świadomość swojego/swoich lęków i stanu/stanów z nim/nimi związanych, przyznaje się do tego/tych stanu/stanów) oraz identyfikację lęku sytuacyjnego (odnosi się do aktualnej i/lub konkretnej sytuacji, trwa stosunkowo krótko, zależnie od sytuacji, która go wywołała) i tzw. ogólnej lękliwości (jest cechą trwałą, niezależną od sytuacji) (Karolczak-Biernacka 1998: 194).

Pojęcie stresu w psychologii jest definiowane niejednoznacznie. Zasadniczo opisuje pewnego typu zjawiska biologiczne, występujące $w$ organizmie pod wpływem różnych zewnętrznych bodźców wyzwalających stres i nazywanych stresorami. Bardzo często stres jest ujmowany jako specyficzny stan organizmu wywołany przez czynniki zewnętrzne. Termin stres jest stosowany jako synonim pojęć/określeń: lęk, konflikt, zaangażowanie ego, frustracja, zagrożenie, emocjonalność, trudności subiektywnej, sytuacji trudnej (Karolczak-Biernacka 1998: 194). Fobia (phobia) z kolei jest rozumiana jako stała tendencja do unikania określonych sytuacji i występowania lęku, jeżeli do tej sytuacji dojdzie. Jest także określana jako lęk takiej sytuacji. Często łączy się z objawami wegetatywnymi, szczególnie związanymi z układem krążenia, oddechowym, obawą utraty przytomności, a nawet śmierci (Pużyński 1993: 160-161).

W klasyfikacji ICD 10 (2009: 225-226) obecne jest odniesienie zarówno do zagadnienia lęku jak i fobii. Jeśli chodzi o lęk przyjęto typologizację oraz kodyfikację oznaczoną symbolem F41 - inne zaburzenia lękowe, w ramach których wymieniono między innymi: zaburzenia lękowe z napadami lęku (lęk paniczny) - F41.0, zaburzenia lękowe uogólnione - F41.1, zaburzenia depresyjne i lękowe mieszane F41.2, inne mieszane zaburzenia lękowe - F41.3, inne określone zaburzenia lękowe (w tym histeria lekowa)-F41.8, zaburzenia lekowe nieokreślone -F41.9 (lęk BNO).

Natomiast w stosunku do fobii - zaburzeń lękowych w postaci fobii - F40 w ICD 10 (2009: 225) podano rozróżnienia lękowe obejmujące agorafobię (F40.0), fobie społeczne (F40.1), specyficzne (izolowane) postacie fobii, w tym akrofobia, fobie związane ze zwierzętami, klaustrofobia (F40.2), inne zaburzenia lękowe w postaci fobii (F.40.8), fobie nieokreślone - fobia BNO, stan fobii BNO (F40.9). 


\section{Lęk i stany depresyjne u osób z niepełnosprawnością wzrokową w świetle wybranych badań empirycznych}

Utrata wzroku jest jedną z głównych przyczyn niepełnosprawności u osób starszych i wiąże się z obniżeniem jakości życia, nasileniem objawów depresji oraz lęku. Z kolei depresja i lęk mogą powodować dalszy spadek jakości życia, nasilać się w okolicznościach obecności niepełnosprawności (w tym niepełnosprawności wzrokowej), zwiększyć podatność na utratę zdrowia (van der Aa, Comijs, Penninx, van Rens, Nipsen 2015). Szacuje się, że w 2020 r. depresja będzie główną przyczyną obciążenia chorobami starszych ludzi. Istniejące analizy demograficzne pokazują, że częstość występowania wad wzroku w krajach rozwiniętych rośnie z powodu starzenia się społeczeństwa. W związku z tym oczekuje się, że obciążenie dotyczące opieki okulistycznej i opieki nad zdrowiem psychicznym osób z wadami wzroku wzrośnie (Vreeken, Rens, van Limburg, Nispen 2014; van der Aa, Comijs, Penninx, van Rens, Nipsen 2015).

Badania naukowe na temat lęku u osób z niepełnosprawnością wzrokową w ostatnich latach były realizowane zasadniczo na gruncie nauk medycznych. I tak, w badaniach naukowych przeprowadzonych przez H.P.A. van der Aa, H.C. Comijs, B.W.J.H. Penninx, G.H.M.B. van Rens, R.M.A. Nipsen (2015) oceniono częstość występowania podprogowej depresji, lęku, głównych zaburzeń depresyjnych, dystymicznych i lękowych (zaburzenia lękowe, agorafobia, fobia społeczna, ogólne zaburzenia lękowe) u niedowidzących starszych osób w podeszłym wieku. Uzyskane szacunki porównywano z danymi zidentyfikowanymi w grupie rówieśników badanych osób z niepełnosprawnością wzrokową, nieposiadających wyraźnych problemów wzrokowych. Badania zrealizowano w Niderlandach i Flandrii (niderlandzkojęzyczna część Belgii), a dane gromadzono od września 2012 r. do lipca 2013 r. Aby móc uczestniczyć w badaniu pacjenci z niepełnosprawnością wzrokową powinni być zarejestrowani w ośrodku rehabilitacyjnym dla osób słabo widzących w Holandii lub Flandrii, posiadać minimalne uszkodzenie wzroku na pograniczu słabo widzenia - ostrość wzroku ?0,52 (20/60 Snellen) i/lub pole widzenia o wartości ?30 ${ }^{\circ}$ wokół centralnego punktu utrwalenia i/lub ewidentne żądanie pomocy, w przypadku którego praktyka okulistyczna nie jest wystarczająca (np. wrażliwość na kontrast i odblaski - w przypadku tego kryterium nie mogli mieć lepszej ostrości wzroku i/lub pola widzenia niż określono to w dwóch pierwszych kryteriach). Powinni być w wieku powyżej 50 lat. Nie mogli być osobami z niepełnosprawnością intelektualną, zaburzeniami psychicznymi. Badani wyrażali pisemną zgodę na udział w badaniach. Generalnie do uczestnictwa w badaniu zaproszono 3000 pacjentów, z których tylko 914 wyraziło pisemną zgodę na udział w badaniach $(30,5 \%)$. Kiedy przesiano grupę potencjalnych uczestni- 
ków badań pod kątem wymaganego minimum niepełnosprawności wzrokowejostrość wzroku ?0,30 (20/40 Snellen) w najlepszym oku, to do badań zakwalifikowano 615 osób. Wszyscy byli powyżej 60 roku życia.

Dane na temat osób starszych z normalnym wiedzeniem z kolei były gromadzone w latach 2008-2009, za pomocą specjalnie uruchomionej strony internetowej oraz z rejestrów mieszkańców z 11 gmin Holandii. Generalnie, z osób z tej grupy, do badań zakwalifikowano 1232 osoby, wszystkie powyżej 60 roku życia oraz ostrością widzenia w lepszym oku od 0,00 do 0,29 (normalne widzenie). W obu populacjach pytano o obecność schorzeń somatycznych, jak: astma lub przewlekłą obturacyjna choroba płuc, choroby serca, choroby tętnic obwodowych, cukrzyca, udar mózgu, zapalenie kości i stawów, nowotwory. W badaniach (w obu populacjach) wykorzystano Skalę Depresji Centrum (CES-D).

Spośród osób niedowidzących ponad 32\% miało progowe objawy depresji $\mathrm{i} /$ lub lęku, w porównaniu do $12 \% \mathrm{w}$ normalnie widzących. 15\% miało podprogowe objawy lęku, w przeciwieństwie do $11 \%$ w normalnie widzących rówieśnikach. Ponadto u 5,4\% niepełnosprawnych wzrokowo stwierdzono ciężkie zaburzenia depresyjne i 7,5\% zaburzenia lękowe zgodnie z DSM-IV, w porównaniu do 1,2\% i 3,2\% normalnie widzących. Szczególnie agorafobię i fobię społeczną. W grupie niedowidzących uzyskano następujące dane: agorafobia $-4,2 \%$, fobia społeczna $-2,4 \%$, co wskazuje, że niedowidzący starsi dorośli są szczególnie podatni na zaburzenia lękowe związane z określonymi miejscami lub sytuacjami, takimi jak: przebywanie $\mathrm{w}$ autobusie, $\mathrm{w}$ tłumie, sytuacje związane $\mathrm{z}$ publicznym mówieniem, spożywaniem posiłków w towarzystwie innych osób. U ponad $10 \%$ niedowidzących zdiagnozowano znaczny poziom depresji i/lub zaburzeń lękowych - w porównaniu do 4,3\% u ich normalnie widzących. Spośród osób niedowidzących 2,3\% miało poważne zaburzenia depresyjne i lękowe; u 42,4\% osób z zaburzeniami depresyjnymi zdiagnozowano również zaburzenia lękowe, a u $30,4 \%$ z zaburzeniami lękowymi zdiagnozowano poważne zaburzenia depresyjne. Spośród osób niedowidzących, więcej niż 11\%, miało poważne zaburzenia depresyjne przynajmniej raz $\mathrm{w}$ życiu, w porównaniu do $4 \%$ ich normalnie widzących rówieśników. Występowanie 1-tygodniowej depresji podprogowej i lęku zdiagnozowano u 32,2\% badanych niepełnosprawnych wzrokowo. W populacji widzących objęły one 12,0\% . 4-tygodniowe rozpowszechnienie lęku podprogowego wynosiło 15,6\% w grupie osób z niepełnosprawnością wzrokową i 10,7\% w grupie osób dobrze widzących. Badania wykazały, że około jedna trzecia niedowidzących starszych osób dorosłych doświadcza klinicznie istotnych objawów depresji i/lub lęku (zwanej depresji podprogowej). W populacji osób starszych depresja, o które mowa występowała w skali około 16\% wśród badanych z tej grupy (van der Aa, Comijs, Penninx, van Rens, Nipsen 2015). 
Wyniki badań zrealizowanych przez A. Augustin, J.A. Sahel, F. Bandello (2007) pokazują, że 30,1\% starszych osób dorosłych ze zwyrodnieniem plamki żółtej z wiekiem spełnia kryteria lęku podprogowego. Natomiast G. Soubrane, A. Cruess, A. Lotery A (2007) oraz E.T. Soubrane, G.I. Kempen, J. Ballemans, A.V. Ranchor, G.H. van Rens, G.A. Zijlstra (2012) porównując osoby starsze z zaburzeniami wzroku i bez nich stwierdzili znacznie wyższe wartości lęku podprogowego w populacji osób niedowidzących. Nie podali jednak wskaźników ich rozpowszechnienia. Stwierdzili, że 13,5\% niewidomych dorosłych cierpiało na podprogowy lęk, w przeciwieństwie do 4,6\% osób niedowidzącymi. 2-tygodniowa częstość występowania ciężkich zaburzeń depresyjnych u osób z niepełnosprawnością wzrokową, wynosząca 5,4\%, była znacznie wyższa niż w populacji normalnie widzących $(1,2 \%)$.

V. Bernabei, V. Morini, F. Moretti (2011) stwierdzili 20,2\% częstości występowania zespołu depresyjnego $u$ osób niedowidzących $w$ porównaniu z 9,3\% w przypadku osób normalnie widzących w wieku ponad 60 lat. Autorzy brali pod uwagę zaburzenia depresyjne i dystymiczne, co spowodowało, że średnia częstość występowania tych dwóch zaburzeń w populacji osób niedowidzących wyniosła 6,4\% (średnia częstość występowania poważnych zaburzeń depresyjnych w społeczeństwie jest szacowana na 1,8\%). W danym badaniu stwierdzono także występowanie około 7\% nasilonych zaburzeń depresyjnych u osób starszych z zaburzeniami wzroku, na podstawie kryteriów DSM-IV.

B.L. Brody, A.C. Gamst, R.A. Williams (2001) w badaniach, w których uczestniczyło 13 pacjentów, wykazali wyższą częstości występowania zaburzeń lękowych w populacji osób z niepełnosprawnością wzrokową (wyniosła 7,5\%) - w porównaniu z normalnie widzącymi rówieśnikami $(3,2 \%)$. Wyjaśniono, że częstość występowania zaburzeń lękowych w próbkach badanych społeczności wahała się od $1,2 \%$ do $15 \%$.

\section{Lęk wysokości - definicje, objawy, źródła, możliwości terapii}

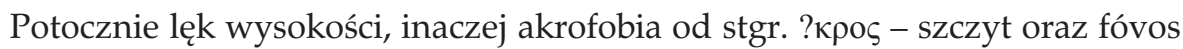
( $\varphi$ óßs) - strach, to najogólniej rzecz ujmując, lęk przed przebywaniem na dużej wysokości, a także przez upadkiem z dużej wysokości (Karolczak-Biernacka 1998: 194; Kacperska 2019). Nie towarzyszy oglądaniu zdjęć, filmów, graniu w gry wideo. Lęk wysokości może pojawiać się w różnych sytuacjach związanych z doświadczaniem wysokości, np. przed skokiem na bungee, w czasie przebywania w bardzo wysokich budynkach, na szczytach gór, czy nawet wchodzenia na drabinę. Lęk wysokości zaliczany jest do fobii specyficznych. Stanowi jedną z najbar- 
dziej znanych postaci zaburzeń lękowych. Z lękiem wysokości jako fobią specyficzną zmaga się od 3 do 5\% ludzi. Problem ten częściej dotyczy kobiet niż mężczyzn (Nipsen 2015).

Nie każdy strach przed znalezieniem się na dużej wysokości można i należy traktować jako fobię. Strach jest uczuciem, które chroni ludzi przed niebezpiecznymi sytuacjami (np. w czasie przechodzenia przez bardzo ruchliwą ulicę $w$ dużym mieście poza miejscem do tego przeznaczonym, wchodzenia na wysoki szczyt, wjeżdżania lub zjeżdżania pojazdem wąskimi drogami w górach), co jest odczuciem naturalnym. O lęku wysokości mówi się wtedy, kiedy w prowokującej strach sytuacji przybiera znaczne natężone objawy, oraz gdy wywiera niekorzystny wpływ na ogólne funkcjonowanie człowieka. Przejawia się nie tylko myślami o zagrożeniu związanym z dużą wysokością, ale i w postaci reakcji somatycznych, a nawet napadu paniki (Kacperska 2019).

Zasadniczo obawy lęku wysokości dotyczą sfery psychicznej i somatycznej. Pierwsze z wymienionych przejawiają się myślami, u osoby doświadczającej lęku wysokości, że za chwilę spadnie z dużej wysokości i poniesie śmierć. Może też mieć wrażenie, że znajduje się na niestabilnym gruncie, że w każdym momencie może zostać przez kogoś popchnięta, upaść, doświadczyć konsekwencji groźnych sytuacji. Wśród najczęściej występujących objawów lęku wysokości wymienia się najczęściej: odczuwanie niepokoju, pojawienie się duszności oraz problemów z oddychaniem (złapaniem powietrza), pocenie się (dłonie), początkowo lekkie, później silne drżenie kończyn dolnych, uczucie „miękkości” nóg, zawroty głowy, bóle głowy, przyspieszona akcja serca, ucisk w klatce piersiowej, ogromny lęk, strach przed upadkiem, strach przed śmiercią (Kacperska 2019).

Przyczyny lęku wysokości, podobnie jak i występowania innych fobii specyficznych, nie zostały dotychczas w pełni wyjaśnione. Istnieją tezy wskazujące, że:

- przyczyną akrofobii mogą być traumatyczne doświadczenia z dzieciństwa (np. upadek z drzewa, urazy związane z upadkiem z większej wysokości);

- lęk wysokości może zostać ukształtowany (wychowany) przez osoby z najbliższego otoczenia (u dzieci osób cierpiących na lęk wysokości, identyczny lub zbliżony problem występuje częściej niż u dzieci osób, które lęku wysokości nie posiadają);

- lęk wysokości jest uwarunkowany historycznie oraz dziedzicznie. Obawy przed wysokością miały chronić populację ludzką przed unicestwieniem. Znajdowanie się na dużych wysokościach łączy się z ryzykiem groźnych dla życia ludzkiego zdarzeń, z których część może się skończyć nawet śmiercią. Stąd, tendencja do lęku wysokości została zapisana w genach, posiada charakter dziedziczny. Nie wszyscy jednak ludzie doświadczają lęku wysokości. Dlatego pod adresem koncepcji dziedziczenia lęku wysokości pojawiają się liczne głosy krytyki (Kacperska 2019). 
Leczenie lęku wysokości jest możliwe, aczkolwiek nie jest to zadanie łatwe. $\mathrm{W}$ stosunku do pacjentów zmagających się z poważnymi i nasilonymi objawami lęku wysokości podejmuje się tzw. terapię ekspozycyjną, opierającą na stopniowym eksponowaniu wobec pacjenta bodźca, będącego źródłem lęku - w przypadku lęku wysokości są to różne, na ogół znaczne, wysokości. Celem tak realizowanej terapii jest desensytyzacja, czyli sprawienie, aby znajdowanie się na dużej wysokości przestało budzić lęk (identyczną terapię stosuje się też wobec osób jąkających się) (Kacperska 2019). Problemem natury organizacyjnej w takiej terapii jest trudność związana z przemieszczaniem się z pacjentem w różne miejsca o znacznych wysokościach. Dlatego coraz częściej wykorzystywane są techniki wirtualne, w których dzięki wykorzystaniu specjalistycznego sprzętu można symulować zadane sytuacje. Inną metodą terapii lęku wysokości jest psychoterapia, a w jej ramach przede wszystkim terapia poznawczo-behawioralna. Jeszcze inną metodą terapii lęku, co prawda rzadko stosowaną i jeśli już to w statusie terapii wspomagającej, jest farmakoterapia. Pacjentom z poważnie nasilonymi objawami lęku wysokości proponuje się leki przeciwdepresyjne przeciwlękowe z grupy benzodiazepin. Podejmuje się też próby łagodzenia objawów somatycznych akrofobii przez stosowanie preparatów z grupy beta-blokerów (Kacperska 2019).

Specyfika lęku wysokości u niewidzących od urodzenia lub wczesnego dzieciństwa w percepcji osób dorosłych niewidzących od urodzenia lub wczesnego dzieciństwa w świetle badań własnych

\section{Założenia badań własnych}

Badania własne zostały zrealizowane w okresie luty--czerwiec 2019 roku. W badaniach wykorzystano metodę indywidualnych przypadków oraz technikę wywiadu. Ze względu na specyfikę problematyki badawczej, specyfikę osób badanej populacji, postawione kryteria doboru osób badanych, ilość badanych, wykorzystaną metodę i technikę badawczą, organizację procesu badawczego, czas realizacji badań, możliwą analizę wyników badań, badania własne zostały ulokowane $\mathrm{w}$ paradygmacie interpretatywnym, który wobec wskazanych założeń wydał się jedynym możliwym i realnym do wykorzystania.

Celem badań było uzyskanie odpowiedzi na pytanie o obecność lęku wysokości u osób niewidzących od urodzenia lub wczesnego dzieciństwa oraz o sposób/ sposoby odczuwania lęku wysokości. Badanym zadano tylko trzy pytania: 1) czy wiedzą co to jest lęk wysokości?, 2) czy odczuwają lęk wysokości? , 3) jeśli odczuwają lęk wysokości, to w jaki sposób się to przejawia, jeśli nie odczuwają lęku wy- 
sokości, to jak sobie wyobrażają w jaki sposób można go odczuwać? W czasie wywiadu wypowiedzi badanych były zapisywane przez realizatorkę badań (nie nagrywano wypowiedzi ze względu na brak zgody badanych na takie rozwiązanie). Uzyskane wyniki zostały poddane opisowi oraz analizie przez autorkę niniejszych badań.

\section{Opis grupy badawczej}

W badaniach własnych uczestniczyło 10 osób dorosłych niewidzących od urodzenia lub bardzo wczesnego dzieciństwa (diagnoza widzenia 0,00), w tym 5 kobiet oraz 5 mężczyzn. Dobór grupy był celowy. Początkowo planowano zorganizować badania na grupie co najmniej 20 osób, jednak 10 osób nie wyraziło zgody na udział w badaniu. Numeracja badanych ciągła, od 1 do 10, była nadawana w pierwszej kolejności dla grupy kobiet, zatem dla grupy mężczyzn na podstawie kryterium daty wyrażenia zgody na udział w badaniu. Badane osoby to podopieczni powstałego 20 sierpnia 2018 r. Gabinetu Rehabilitacji Osób z Dysfunkcją Narządu Wzroku, który funkcjonuje w strukturach Niepublicznego Zakładu Opieki Zdrowotnej Ośrodka Mieszkalno-Rehabilitacyjnego Polskiego Związku Niewidomych w Olsztynie. Pewnym ograniczeniem w doborze badanych było kryterium niewidzenia od urodzenia lub nabycia niewidzenia do 3-go roku życia. Oto krótka charakterystyka badanych osób:

[N1] - kobieta, wiek 59 lat, wykształcenie zawodowe (ślusarz), a kolejno szczotkarstwo, edukacja w systemie specjalnym, od 30 lat podopieczna DPS dla osób z niepełnosprawnościami. Dodatkowe schorzenia: cukrzyca; ponadto nadwaga. Poziom samodzielności ograniczony; wymaga pomocy w przemieszczaniu się i czynnościach codziennych.

[N2] - kobieta, wiek 34 lata, wykształcenie zawodowe - tkactwo, edukacja w systemie specjalnym, podopieczna DPS dla osób z niepełnosprawnościami od 16 lat. Utrata wzroku we wczesnym dzieciństwie na tle glejaka nerwu wzrokowego (do 3. roku życia). Dodatkowe schorzenia: epilepsja. Problemy z pamięcią. Wymaga pomocy w przemieszczaniu się i czynnościach codziennych.

[N3] - kobieta, wiek 35 lat, wykształcenie wyższe pedagogiczne, edukacja w systemie integracyjnym, samodzielna $w$ czynnościach codziennych oraz orientacji przestrzennej - przemieszcza się z pomocą psa przewodnika, pracuje w strukturach samorządowych.

[N4] - kobieta, wiek 46 lat, wykształcenie podstawowe. Edukacja w systemie ogólnodostępnym. Kształciła się w liceum ogólnokształcącym, ale nie skończyła szkoły. Zamężna, posiada dwie dorosłe widzące córki. Mieszka w tzw. mieszkaniach chronionych, przeznaczonych dla osób z niepełnosprawnością wzroku. Pracuje w zakładzie aktywności zawodowej. Samodzielna w czynnościach codziennych, natomiast przy przemieszczaniu się wymaga wsparcia osoby widzącej. 
[N5] - kobieta, wiek 46 lat. Niewidoma od urodzenia, młodszy brat także nie widzi od urodzenia. Edukacja w systemie specjalnym. Wykształcenie zawodowe - obróbka metalu. Pracowała w zakładzie pracy chronionej, jednak po upadku zakładu została bezrobotna. Był moment, że pracowała na umowę zlecenie w bibliotece dla niewidomych, funkcjonującej przy instytucji realizującej opiekę nad daną grupą osób. Rozwiedziona, posiada dorosłą widzącą córkę. W czynnościach codziennych samodzielna, jednak przy przemieszczaniu potrzebuje pomocy przewodnika.

[N6] - mężczyzna, wiek 39 lat, wykształcenie wyższe, edukacja na poziomie podstawowym w szkolnictwie specjalnym, na poziomie średnim w szkolnictwie ogólnodostępnym. Pracuje jako muzyk. Samodzielny w czynnościach codziennych oraz przy przemieszczaniu się po znanych trasach; nieznane trasy sprawiają duże problemy. Rozwiedziony, nie ma dzieci.

[N7] - mężczyzna, wiek 32 lata, wykształcenie średnie (bez matury), edukacja w systemie integracyjnym, średnia skończona szkoła muzyczna. Samodzielny w czynnościach codziennych, wymaga wsparcia w orientacji przestrzennej. Pracuje w strukturach samorządowych. Żonaty - żona słabo widząca.

[N8] - mężczyzna, wiek 62 lata. Resztki wzrokowe od urodzenia (poczucie światła), zatem całkowita utrata wzroku w wieku 12. lat. Edukacja na poziomie podstawowym w systemie specjalnym, szkoły średniej - ogólnodostępnym. Wykształcenie wyższe informatyczne. Aktywny działacz na rzecz osób z niepełnosprawnością wzroku. Żonaty - żona widząca, dwóch synów z niepełnosprawnością widzenia. Samodzielny w czynnościach codziennych, w czasie przemieszczania się wymaga wsparcia przewodnika widzącego.

[N9] - mężczyzna, wiek 62 lata. Edukacja w systemie specjalnym (szkoła podstawowa) oraz ogólnodostępnym (szkoła średnia). Wykształcenie wyższe humanistyczne. Aktywnie działa na rzecz osób niewidzących, szczególnie w obszarze sportowym. Żonaty, żona widząca dwoje dorosłych widzących dzieci. W czynnościach codziennych samodzielny, zaś w czasie przemieszczania się potrzebuje wsparcia widzącego przewodnika.

[N10] - mężczyzna, 32 lata. Niewidzący od urodzenia. Rodzice również są osobami niewidomymi. Edukacja w systemie specjalnym. Wykształcenie zawodowe - obróbka metalu. Nie pracuje. Angażuje się w sport osób niewidzących - strzelectwo. Nie pracuje, nieżonaty.

\section{Wyniki badań własnych}

Poniżej, zasadniczo w formie opisowej (nie dosłownej), na podstawie notatek poczynionych w czasie wywiadu przez badającą (chociaż w wybranych przypadkach pojawią się dosłowne cytowania) przedstawiono wypowiedzi badanych osób na temat lęku wysokości, aczkolwiek już w tym momencie można wskazać na wniosek (być może wynika on ze składu osobowego grupy badawczej) o tym, 
że o ile badane kobiety deklarują jednoznacznie brak poczucia lęku wysokości, o tyle wśród badanych mężczyzn sytuacja nie jest już tak jednoznaczna i oczywista.

Kobieta [N1] stwierdziła, że nie ma lęku wysokości i trudno jej wyobrazić sobie jakie odczucia towarzyszą temu lękowi. odniosła się do wspomnień związanych z pobytem na najwyższym piętrze Pałacu Kultury w Warszawie. Jechała windą i nie odczuwała niczego, co można łączyć z lękiem wysokości. Podobnie było jak dojechała na najwyższe piętro tego gmachu. Jednocześnie na pytanie, jak sobie wyobraża lęk wysokości, podała przykład, iż zapewne bałaby się skoczyć z piętrowego łóżka, ale wysokości w Pałacu Kultury nie obawiała się i żadnych przeczuć/odczuć, które można ulokować w sferze lęku wysokości nie doświadczyła.

Kobieta [N2] - nie wyobraża sobie lęku wysokości oraz nie odczuwa jego konsekwencji. Zasłania się przy tym problemami z pamięcią, twierdząc, że nie przypomina sobie sytuacji związanych z takim lękiem. Będąc na dużych wysokościach $\mathrm{w}$ miejscach otwartych, poza budynkami, odczuwała (odczuwa) jedynie opływ powietrza na twarzy, ale stanów lęku nie i nawet jeśli wyglądałaby przez okno z wysokiego budynku to nie bałaby się takiej sytuacji, chociaż wie, że jest groźna i nieostrożne zachowanie może doprowadzić nawet do śmierci.

Kobieta [N3] - udzieliła niemal identycznej odpowiedzi, jak przywołane wyżej badane. Nie odczuwa lęku wysokości nawet w bardzo wysokich budynkach, a możliwe powiązanie lęku wysokości skojarza z sytuacją wchodzenia i schodzenia po schodach.

Badana [N4] mówiąc o lęku wysokości oraz o skojarzeniu tegoż lęku z możliwym konkretnym przykładem przywołała sytuację mycia okien na trzecim piętrz, chociaż nigdy nie robiła tego samodzielnie. Ma bowiem świadomość, że mogłaby wypaść z takiej wysokości i zginąć.

Badana [N5] w czasie wywiadu opowiedziała o wycieczce z córką do Francji, o zwiedzaniu wieży Eiffla w Paryżu. Wchodziły na pierwszy poziom schodami (podobnie też schodziły). Nie miała przy tym jakiegoś wyraźnego lęku, poza odczuciami dotykowymi związanymi z opływem powietrza oraz pokonywaniem schodów przy wchodzeniu i schodzeniu.

Badany [N6] - realizując obowiązki wynikające z wykonywanej pracy często spotyka się z różnymi ludźmi w różnych budynkach, także tych bardzo wysokich. Stąd ewentualne wysokości kojarzy z wchodzeniem lub schodzeniem po/ze schodów oraz z wjeżdżaniem windą na określone piętro.

Badany [N7] - pracuje jako trębacz w dużym mieście, codziennie gra na trąbce lokalny hymn $\mathrm{z}$ wieży ratuszowej, dlatego $\mathrm{w}$ jego wypowiedzi o istocie lęku wysokości pojawiły się asocjacje lęku wysokości z pokonywaniem schodów (z wchodzeniem i schodzeniem po/ze schodach/schodów).

Badany [N8] o doświadczaniu lęku wysokości mówił następująco: Czy osoby niewidome od urodzenia odczuwają lęk, np. wysokości czy głębokości. Oczywiśsie tak. Sq one obecne, jak u wszystkich ludzi. Mogę powiedzieć więcej, że z powodu wyobraźni i fantazjowania musza być 
wyrysowane i czasami sa przerysowane w stosunku do realnej rzeczywistości. Pamiętam sytuację, która wydarzyła się w czasie wakacji nad morzem. Miałem wtedy 14 lat. Widzace dzieci skakały do wody z niewielkiej skaty. Bawity się znakomicie. Nakłonitem rodziców, aby pozwolili mi skoczyć do wody, a ptywałem nieźle. Jednak żeby skoczyć do wody trzeba było wejść z brzegu na wysokość około dwóch metrów. Skoczyć nie mogłem. Podchodziłem do granicy skałki i cofatem sie z powrotem, przykucałem, brałem głęboki oddech. I tak kilka razy. Nie zdecydowałem się na skok. Pomyślatem sobie, że gdybym był widzącym, to zrobiłbym to bez wahania.

Badany [N9] z kolei podkreślił: Nie rozumiem jak można bać się czegoś czego nie widać, czegoś, czego się nie widzi, chyba że ten strach występuje w innej niż tradycyjna postaci. Prawda jest, że jeżeli czegoś nie widzę, to nie znaczy, że tego nie ma. Ale z tym lękiem u niewidomych może być inaczej. Kiedy u osób widzących, np. lęk wysokości bądź widok pająka wywołuje lęk, to niewidomy nie zobaczy pająka i nie popatrzy z wysokości. Wtedy albo nie odczuwa lęku, albo odczuwa bez udziału obrazów wzrokowych. Poprzez fantazję, odczucia wewnętrzne, optyw powietrza wokót ciała (szczególnie twarzy), informacje słowne uzyskane od osób widzących.

Badany [N10] - częste wyjazdy na zawody sportowe wiążą się z zamieszkiwaniem w różnych hotelach, dlatego wyobrażenie lęku wysokości skojarza z pokonywaniem schodów lub wjeżdżaniem windą na wybrane piętro. W jego wypowiedzi pojawiła się ponadto sugestia, że nawet słyszany przez niego komunikat $\mathrm{w}$ windzie mówionej o wjechaniu na bardzo wysokie piętro nie wywołuje w nim jakichkolwiek szczególnych odczuć natury lękowej.

Wniosek: badane kobiety odczuwanie lęku wysokości kojarzą z sytuacjami lub czynnościami, w których mają do czynienia z wysokością (np. wchodzenie, schodzenie po schodach, schodzenie z piętrowego łóżka, wyglądanie przez okno). Natomiast badani mężczyźni zasadniczo poczucie lęku wysokości wpisują w wykonywaną aktywność zawodową czy realizowane hobby (np. uprawianie sportu).

\section{Podsumowanie}

Problematyka lęku u osób niewidzących od urodzenia lub wczesnego dzieciństwa do chwili obecnej nie została jeszcze w pełni poznana. Co prawda w literaturze naukowej obecne są opisy badań na temat stanów lęku, stanów depresyjnych czy wręcz depresji u osób z niepełnosprawnością wzrokową, nie ma natomiast poza prezentacją indywidualnych przypadków lub wyników badań na generalnie mało licznych populacjach - szerszych doniesień na temat lęku wysokości w danej grupie ludzkiej. To powoduje, że sytuacja eksploracji zagadnienia lęku, w tym lęku wysokości, u osób z niepełnosprawnością wzrokową jest wysoce niejednoznaczna. Istnieją osoby niewidzące od urodzenia lub wczesnego dzieciństwa (i stanowią one kategorię dominującą) twierdzące, że nie doświadczają 
ewentualnych odczuć mogących korelować z lękiem wysokości, a jeżeli już pojawiają się jakiekolwiek wyobrażenia, to obejmują one okoliczności mierzone doświadczeniem przemieszczania się $\mathrm{w}$ przestrzeni. Istnieją też osoby (stanowiące zdecydowaną mniejszość), które odczuwają lęk wysokość w sytuacjach przestrzennych dotychczas im nieznanych, ale wyobrażanych jako mogące stanowić zagrożenie (bez względu na wysokość powiązaną z daną sytuacją) lub w sytuacjach doświadczania znacznych wysokości odbieranych dotykowo (opływ powietrza na twarzy), albo kinestetycznie (odczucia towarzyszące wjeżdżaniu i zjeżdżaniu windą w wysokich budynkach).

Konkludując powyższe rozważania, poza wnioskiem o potrzebie badań naukowych nad sygnalizowanym zagadnieniem, warto przytoczyć fragment relacji głuchoniewidomej Olgi Skorochodowej, która pisząc o odczuwaniu przez siebie lęku wysokości przywołała przykład pobytu w sanatorium: „Sanatorium znajdowało się w otoczeniu gór i lasów, które nie wywoływały we mnie żadnych szczególnych odczuć. Niedaleko od budynków sanatorium znajdował się wielki most łączący dwie góry nad przepaścią. Nazywał się mostem miłości i zdrady. Pewnego razu z M.N. oraz z kilkoma innymi pensjonariuszkami wybrałyśmy się na ten most. (...) Przeszłam wspólnie z M.N. przez środek mostu. Nie odczuwałam żadnego lęku. Zatem M.N. oprowadziła mnie jeszcze raz po moście. Szłyśmy przy niewysokich barierkach znajdujących się z obu jego stron. Mówiła mi, że przepaść jest przeogromna i upadek grozi śmiercią. Równocześnie asekurowała mnie wszelkimi możliwymi sposobami, obawiając się niespodziewanego zachwiania równowagi, tym bardziej, że w niektórych miejscach barierki były w bardzo złym stanie. Jednakże w mojej wyobraźni nie doświadczyłam najmniejszej reakcji co do głębokości przepaści oraz przerażenia, które może ona wywoływać w osobach widzących" (Skorochodowa 1956: 317 - tłumaczenie własne).

\section{Bibliografia}

Aa H.P.A. van der, Comijs H.C., Penninx B.W.J.H., Rens G.H.M.B. Nipsen R.M.A. (2015), Major Depressive and Anxiety Disorders in Visually Impaired Older Adults, Investigative Ophthalmology \& Visual Science, vol. 56, 849-854.

Augustin A., Sahel J.A., Bandello F. (2007), Anxiety and depression prevalence rates in age-related macular degeneration, Invest Ophthalmol Vis Sci, 7, 1498-1503.

Bernabei V., Morini V., Moretti F. (2011), Vision and hearing impairments are associated with depressive-anxiety syndrome in Italian elderly, Aging Ment Health, 467-474.

Brody B.L. Gamst A.C., Williams R.A. (2001), Depression, visual acuity, comorbidity, and disability associated with age-related macular degeneration, Ophthalmology, 1893-1900.

Delacato C.H. (1999), Dziwne, niepojęte. Autystyczne dziecko, Fundacja Synapsis, Warszawa. ICD-10. Międzynarodowa Statystyczna Klasyfikacja Chorób i Problemów Zdrowotnych, t. 1 (2009), World Health Organization, Centrum Systemów Informacyjnych, Warszawa. 
Kacperska M.J. (2019), Akrofobia, lęk wysokości - objawy, diagnoza, leczenie, http://www.psychiatria.pl/porada/akrofobia-lek-wysokosci-objawy-diagnoza-leczenie/3771 [dostęp: 11.02.2019].

Karolczak-Biernacka B. (1998), Lęk i stres w sporcie [w:] W. Szewczuk (red.), Encyklopedia psychologii, Wydawnictwo Fundacja „Innowacja”, Warszawa, 193-194.

Nipsen R.M.A. van (2015), Investigative, Ophthalmology \& Visual Science, vol. 56, 849-854.

Obuchowska I. (1993), Lęk szkolny [w:] W. Pomykało (red.), Encyklopedia pedagogiczna, Wydawnictwo Fundacja „Innowacja”, Warszawa, 344-346.

Pużyński S. (1993), Lęk [w:] Leksykon psychiatrii, PZWL, Warszawa, 247-250.

Pużyński S. (1993), Fobia, [w:] Leksykon psychiatrii, PZWL, Warszawa, 160-161.

Skorochodowa O.I. (1956), Jak postrzegam świat, Wydawnictwo Akademii Nauk Pedagogicznych, Moskwa (О.И. Скороходова, Как я воспринимаю и представляю окружающий мир, Издательство Академии Педагогических Наук, Москва).

Soubrane E.T., Kempen G.I., Ballemans J., Ranchor A.V., Rens G.H. van, Zijlstra G.A. (2012), The impact of low vision on activities of daily living, symptoms of depression, feelings of anxiety and social support in community-living older adults seeking vision rehabilitation services, Qual Life Res, 21(8), 1405-1411.

Soubrane G., Cruess A., Lotery A. (2007), Burden and health care resource utilization in neovascular age-related macular degeneration: findings of a multicountry study, Arch Ophthalmol., 1249-1254.

Vreeken H. van, Rens G., Limburg H. van, Nispen R. (2019), Definities, epidemiologie en organisatie van de zorg voor blinden en slechtzienden in Nederland [Definitions, epidemiology and organisation of care for the blind and visually impaired in the Netherlands] [w:] G. van Rens, H. van Vreeken, R. Nispen (ed.), Richtlijn Visusstoornissen: Revalidatie en Verwijzing [Guideline Vision Disorders: Rehabilitation and Referral], NIZW Publisher, Utrecht, 15-30, http://www.reponline.nl/uploads/hC/sf/hCsfyQHBvekdnF3fp-z2xw/ Richtlijn-visusstoornissen-revalidatie-en-verwijzing.pdf [dostęp: 30.03.2019]. 